\title{
1 Ronald Coase: the makings of an iconoclast
}

\author{
Mary M. Shirley
}

\section{EARLY INFLUENCES}

Ronald Coase was an intellectual rebel - a courteous, generous, and witty scholar, but a rebel nonetheless. From his twenties until his death at 102, he sought answers to questions that most economists ignored. Why are there firms? What would really happen if we set prices equal to marginal cost? If the lighthouse is the iconic public good, have there ever been private lighthouses? What happens when one economic activity imposes costs on other economic actors - and what are the consequences of the ways we try to "fix" this problem? These questions distinguished Coase from mainstream economists, but so too did his answers and his way of finding answers through painstaking scrutiny of evidence.

Born in London in December 1910, Coase had a weakness in his legs that forced him to spend his early years at a school for physical defectives, where they taught him basket weaving (Coase 1995). This unlikely beginning did not stop him from entering the Kilburn Grammar School at 12, and after graduation, the London School of Economics. Coase pursued a bachelor of commerce degree at LSE, which at that time focused on practical problems of business, much like today's MBA. This early training inculcated Coase's concentration on real world problems, an orientation that proved to be at odds with the dominant trends in economics. An even greater influence on Coase's future was Arnold Plant, whose lectures on economics, which Coase attended at LSE, were a "revelation" to the young Coase (Coase 1992: 715).

Much as Coase admired Plant, he was already questioning authority. Plant, arguing against schemes to solve the Great Depression by using central planning to coordinate production, said that competition "acting through a system of prices would provide all the coordination necessary" (ibid.). Coase believed that Plant's argument created a puzzle: ". . . we had in economics a factor of production, management, whose function is to coordinate" (ibid.). If the pricing system provided all the coordination needed, as Plant argued, then why do we need management? Why do we need firms?

Coase's curiosity was fed when he was awarded a Cassel Traveling 
Scholarship, allowing him to spend his final year of study (1931-32) traveling in the United States and meeting businessmen struggling with the practical consequences of the Great Depression. The businessmen spoke freely with the 21 year old Coase, and he gradually formed an answer to his question, an answer which became the basis for his landmark paper, "The Nature of the Firm" (1937). We need coordination by management because there are costs to using the price mechanism, costs that are high enough under some circumstances to make it more efficient to organize production in a firm. These costs, subsequently termed transaction costs, are the costs "of discovering what the relevant prices are" (1937: 390), and "of negotiating and concluding a separate contract for each exchange transaction which takes place on a market" (390-91). While transaction costs are very familiar to us now, at the time no one analyzed why some economic activity was organized through markets and some through firms; the choice was taken as given. Coase gained new insights by asking questions no one else was asking and finding answers through intensive empirical research, a methodology that many economists increasingly demeaned.

After graduation from LSE, Coase became an assistant lecturer first at the Dundee School of Economics and Commerce (1932-34), then at the University of Liverpool (1934-35), and, starting in 1935, at the London School of Economics. He began "to read the literature of economics Adam Smith, Babbage, Jervons, Wicksteed, Knight" (Coase 1995) - and to study monopoly theory, accounting, and public utilities, earning a Doctor of Science degree in economics from the University of London in 1951.

His research on public utilities made Coase "aware of the defects of government operation of these industries" (1996: 106), and led him gradually to abandon his youthful socialism. His socialist sympathies were "not unusual at the time", but were "inconsistent" with his views about the disadvantages of ill-conceived government interventions (ibid.). From then on, Coase sought to take positions grounded in empirical observation and careful study of the practical consequences of alternatives; he never again settled for the "usual". For example, although Coase was skeptical about the advantages of government intervention, he did not assume that all government interventions were necessarily bad. He argued that economists could only discover the appropriate boundary for government action by means of "a detailed investigation of the actual results of handling the problem in different ways" (Coase 1960: 13).

Coase's stress on factual investigation and analysis of practical consequences led him into conflict with other economists, as was evidenced early on with "The Marginal Cost Controversy" (1946). Proponents of setting prices for regulated utilities based on marginal costs argued that when average costs were above marginal costs, government should subsidize the 
losses that would inevitably result. Coase pointed out numerous problems. One was that prices set equal to marginal costs would provide no market signal about future investment. Other problems included strong political pressures to increase the subsidy, and the redistribution of income to consumers of products facing decreasing average costs. Coase later asked why there was widespread support among economists for marginal cost pricing, "a policy largely without merit" (1990: 19). He attributed it to blackboard economics, "a system which lives in the minds of economists but not on earth" (Coase 1992: 714). In blackboard economics, "all the information needed is assumed to be available and the teacher plays all the parts. He fixes prices, imposes taxes, and distributes subsidies (on the blackboard) to promote the general welfare. But there is no counterpart to the teacher within the real economic system" (Coase 1990: 19). Blackboard economics "misdirects our attention when thinking about economic policy. For this we need to consider the way in which the economic system would work with alternative institutional structures" (19-20). Coase saw Darwin as an appropriate role model for scholars: meticulous data collection and bold but realistic theorizing (see Wang 2014).

Probing the practical consequences, asking uncommon questions, and keenly investigating reality, these early traits became hallmarks of Coase's later research.

\section{MAKING WAVES AND BUILDING INFLUENCE}

In 1951, prompted by "a lack of faith in the future of socialist Britain", and "an admiration for American economics", Coase moved to the Economics Department of the University of Buffalo in the United States (Coase 1995: 239-40). In 1958 he moved again to teach economics at the University of Virginia, where he joined James Buchanan, Warren Nutter, and other economists at the Thomas Jefferson Center (TJC) for Studies in Political Economy (Levy and Peart 2014). Here Coase got involved in a contretemps when the Ford Foundation rejected the TJC's 1960 proposal for funding, on the grounds that the TJC espoused a single "point of view" (ibid.: 2). At a contentious meeting with two of the Ford Foundation staff, Coase countered their insinuation that the TJC was "propagandist" rather than a "serious research program" by asserting that he was "in the habit of presenting my views with moderation and respect for opposing views" (Coase's report on the meeting in Levy and Peart 2014: 42). Later, in a letter to his interlocutor at Ford, Coase reported that he was "deeply depressed" by their meeting (p. 26), a reaction that is especially understandable given Coase's own intellectual journey and his 
oft-voiced commitment to free inquiry as a basis for his positions. This led to frictions between the University of Virginia and the TJC, and it is not surprising that Coase moved in 1964 to the University of Chicago Law School. ${ }^{1}$ Chicago offered him the opportunity to edit the Journal of Law and Economics, which Coase saw as a platform to change economics.

During this period, Coase was working on a paper that would have major repercussions on regulatory policy and his own career. "The Federal Communications Commission" (1959) argued that the FCC's allocation of radio frequencies by administrative fiat created undesirable political control over the airways and could threaten freedom of the press, just as free speech is threatened when government decides who should publish newspapers. He proposed that the FCC instead sell the rights to radio spectrum frequencies to private owners. In a pivotal passage, Coase argued that if rights were well defined and transferable and transaction costs were low enough, the initial assignment of rights would not matter; they would be traded and combined in ways that would maximize output. The resulting owners would have more incentive to invest in new technology, adapt to changing markets, and operate efficiently. As for the FCC's concern that private control would lead to interference between signals broadcast on adjacent frequencies, Coase reasoned that owners with clear property rights would want to maximize the value of their assets by negotiating agreements or developing technologies that minimize interference.

Coase's argument eventually won the day, and spectrum actions are now widespread, but the initial response was strong opposition. ${ }^{2}$ In a hearing on the article, the FCC Commissioner asked Coase, "Are you spoofing us? Is this all a big joke?" (Coase 1998: 597). More important for Coase's future was the reaction of a group of economists at the University of Chicago. They believed Coase had made an error in his discussion of tradable rights and invited him to a meeting at the home of Aaron Director to discuss his "mistake". Those present initially objected to Coase's "heresy"; Milton Freidman was an especially vocal opponent (Stigler 1988). Yet by the end of the meeting, they were convinced, and asked Coase to write up his argument for the Journal of Law and Economics. The resulting article "The Problem of Social Cost" (1960) - was a milestone in economics, cited by the Nobel committee when they awarded Coase the Prize. ${ }^{3}$

Coase's concern was with what most economists now term externalities: the costs that arise when a business activity harms another economic actor. The interference between radio frequencies is an example, as is noise from a bakery disturbing a neighboring doctor's office. Coase took issue with the usual remedies. Most economists followed Pigou (1932) in arguing that the firm "causing" the harm, such as the bakery, should be liable for the damage, subject to a tax equivalent to the potential damage, or 
regulated as to where it could locate. Coase (1960) maintained that these Pigouvian remedies obscured an important characteristic - the reciprocal nature of the problem. The doctor would not have been disturbed if the bakery did not make noise, but the bakery would have disturbed no one if the doctor had not set up his office where he did. "If we are to attain an optimum allocation of resources, it is therefore desirable that both parties should take the harmful effect (the nuisance) into account in deciding on their course of action" (1960: 13). Moreover, all the proposed remedies have costs as well, and economists should consider all costs, comparing "the total product yielded by alternative social arrangements", and they should do so, not by comparing a "state of laissez faire and some kind of idea world", but by starting the analysis "with a situation approximating that which actually exists" (1960: 43).

Coase presented two scenarios in "The Problem of Social Cost", one under positive transaction costs and one where he assumed the costs of transacting was zero. With zero transaction costs, the economic actors - the bakery and the doctor or the owners of adjacent radio frequencies - could costlessly bargain to allocate rights in a way that would maximize the value of production; the initial legal assignment of those rights would not matter. This was the same argument that had earlier led to the meeting at Aaron Director's house; it is the argument that Stigler labeled the Coase theorem (1966). Although economists have written extensively about the Coase theorem, many failed to recognize that Coase did not advocate addressing harms by means of the Coase Theorem. ${ }^{4}$ To the contrary, Coase believed economists should study alternative remedies using a realistic evaluation of positive transaction costs, in which case liability would matter a great deal. Economists' preoccupation with zero transaction costs perturbed Coase. To him, the insights gained from studying a world of zero transaction costs were

without value except as steps on the way to the analysis of the real world of positive transaction costs. We do not do well to devote ourselves to a detailed study of the world of zero transaction costs, like augurs divining the future by the minute inspection of the entrails of a goose. ([1981] 1994b: 187)

Once again, Coase parted company with mainstream economists, in this case with the many that delighted in analyzing the imaginary world of zero transaction costs.

After his move to Chicago in 1964, Coase became editor of the Journal of Law and Economics, where he actively promoted articles that overturned conventional wisdom by careful empirical research. "Coase sought out and encouraged faculty members at Chicago and elsewhere to examine how particular markets actually worked, what factors determined the types of transactions and contracts that parties entered into, and the role of laws and legal institutions in shaping markets" (Landes et al. 1983: 
iii-iv). The net effect, as Hayek put it (in a 1984 letter nominating Coase for the Nobel Prize), was to develop

what amounts in effect to a new branch of economic theory of great realistic application, a development he has painstakingly assisted by his work as editor of the Journal of Law and Economics of which he was for 16 years an editor who in a rare manner assisted and guided his contributors.

Coase did not initially set out to challenge authority or oppose conventional economics; his iconoclasm was a by-product of the clash between his preference for empiricism and practicality and orthodox economists' fondness for abstraction and mathematics. Coase criticized what he called "mindless abstraction or the kind of abstraction which does not help us to understand the workings of the economics system" (Coase 1993: 97). He disliked mindless abstraction, but he hated sloppy empiricism that failed to understand or even care about the real world. We can see this in his 1974 article, "The Lighthouse in Economics." Numerous economists had used the lighthouse as the ideal example of a public good: a lighthouse saves lives and money, but as there is no way for the private sector to solve the free rider problem, government should provide it for free. Coase's research showed that at one time many lighthouses in the UK were in fact private; for example, in 1820 the majority of lighthouses were built and operated by private owners and financed by a toll on ships docking in nearby ports. Economists had not studied the lighthouse before citing it; rather, "The lighthouse is simply plucked out of the air to serve as an illustration ..." (Coase 1974: 375). As with marginal cost pricing, Coase saw the lighthouse as another damning example of blackboard economics.

Coase argued for realism and empirical investigation, but that did not mean that he was against theory. ${ }^{5}$ To the contrary, he himself was a consummate theorist; he saw theory as essential for understanding reality. ${ }^{6} \mathrm{He}$ disputed Friedman's assertion that economic theory should be judged by, "the precision, scope and conformity with experience of the prediction it yields", and not by whether its assumptions are realistic ([1952] 1966: 4). Coase argued that, "We are not interested simply in the accuracy of its predictions. A theory also serves as a base for thinking. It helps us organize our thoughts" ([1981] 1994b: 16). Coase also challenged the idea that economists develop theories and then test the theoretical predictions against empirical observation, saying, "economists do not wait to discover whether a theory's predictions are accurate before making up their minds" (ibid.: 24). That explains why economists tend to get the result that theory tells them to expect: "if you torture the data enough, nature will always confess ..." (27). And when the results do not confirm the theory, economists seldom abandon the theory, "rather the discrepancies are put on one side as calling for further study" (ibid.). Instead of choosing theories based on the 
accuracy of their predictions, Coase argued that we should chose theories for the insights they give us into how the economic system actually works.

\section{A REBEL TO THE END}

Coase became emeritus at the University of Chicago in 1982, but he continued to publish and to challenge orthodoxy until his death in 2013 at nearly 103. When he accepted the 1991 Nobel Prize, his acceptance speech not only stated his views about the primacy of transaction costs and the importance of institutions to understanding economic phenomena, it also gave a masterful critique of economics in typical Coasean style: witty, selfeffacing, and free of rancor (Coase 1992). He said that his contribution to economics was to urge inclusion of neglected features of the economic system, such as firms, transaction costs, and institutions. Economics ignored these features because of its focus on price theory to the neglect of everything else and "the growing abstraction of the analysis, which does not seem to call for a detailed knowledge of the actual economic system or, at any rate, has managed to proceed without it" (1992: 714). Coase hoped that the encouragement given to researchers by his Nobel Prize would reduce the "elegant but sterile theorizing so commonly found in the economics literature on industrial organization and should lead to studies which increase our understanding of how the real economic system works" (1992: 719).

In his Nobel speech, Coase called on economists to study "the institutional structure of production," and he acted to further his goal by supporting data collections and initiatives to encourage research using new institutional economics. For example, in 2000 he helped found the Ronald Coase Institute, which supports research to better understand how real economic systems work, and assists young scholars study institutional problems in their own countries. ${ }^{7}$ Coase also helped found the International Society for New Institutional Economics (ISNIE) in 1997, was its first president, and helped it raise funds for young scholars to participate in its meetings. In a 1999 speech to ISNIE, Coase asserted that ISNIE was a society with a mission, "and that mission is to transform economics", replacing price theory with "something better, the New Institutional Economics" (1999: 1). He called for members to be openminded and support one another, to recognize that "We do not know, for the most part, what is true or what is false, what is significant and what is not, nor the character of the interrelations of various parts of the institutional structure of the economy. It is our aim to find out" (ibid.: 6).

Coase never retired from economics and he never lost his gracious and tolerant form of iconoclasm. In his later years, he challenged others' 
interpretations of his works (such as Richard Posner in 1993 and A.W. Brian Simpson in 1996). And he disputed another of economics' paradigmatic examples. The Fisher Body case was widely cited as a poster child for "hold up", which occurs when a supplier threatens to interrupt delivery of an essential and (at least in the short run) irreplaceable input unless paid what the purchasers regard as an unreasonably high price. Fisher Body supplied bodies to most General Motors' cars under an exclusive contract. In a famous paper, Klein et al. (1978) argued that General Motors took over Fisher Body to prevent hold up, but Coase (2000, 2006), after in depth study of the contract and other documents, argued that there was no evidence of hold up. Coase saw Fisher Body, like the lighthouse, as a case of economists failing to analyze and understand fully the phenomenon they purported to explain.

In his later years, Coase focused on China, convinced that a better understanding of China's extraordinary transition would improve and enrich economists' understanding of the influence of institutions on economic systems more broadly (see Coase 2010). Since it was difficult for him to travel to China, he did his field research by bringing the field to him. He invited Chinese scholars to visit him at the University of Chicago, kept in close contact with prominent scholars in China, such as Stephen Cheung, and initiated and financed two conferences in 2008 and 2010 that brought the Chinese scholars, officials, and business people he most wanted to interview to Chicago. With Ning Wang he co-authored a book on China (2012), published when he was 102. True to Coase's practice, the book delved deeply into China's history and institutions, and reached conclusions that defied conventional wisdom on China, arguing that it was not central government reforms that were responsible for reintroducing markets and entrepreneurship in China, but "marginal revolutions". Marginal revolutions, such as the decollectivization of farms, were led by local government officials competing for promotions and local businesses owners competing for markets and resources. The central government's most important action was to tolerate the initial experiments and promote the successful ones.

\section{LESSONS FOR ECONOMISTS}

Coase left economists an invaluable legacy of ideas, but he also bequeathed a set of guiding principles for good economic practice, including respect for reality, analysis of alternatives, and consideration of practical consequences. But economists trying to follow Coase's principles face high hurdles. As Peltzman argues, most formal university training stresses theory and modeling; "relatively little formal training prepares the young economists for confronting nuances of actual data" (2011: S25). And there 
are few incentives: economics tends "to value theoretical and conceptual work as somehow more valuable or of a higher order than empirical work", and that has led to "a diversion of effort from the empirical to the theoretical" (ibid.: S26). To win tenure and recognition, young economists have to publish in first ranked journals, and "straightforward model-free empirical analysis" (ibid.: S25) is hard to publish. Following Coase's advice would yield academic rewards that are meager or nil. Since analysis of the practical consequences of realistic alternatives is demanding in effort, time, and money, it is also, not surprisingly, rare. ${ }^{8}$ Yet Coase himself was optimistic that young scholars, especially those from developing countries who are less socialized to undervalue empirical work, would overcome these hurdles and do research on real world institutions that would change the way we view problems. ${ }^{9} \mathrm{He}$ also believed that such transformative work would eventually be accepted by other economists, as long as there was a competitive market for ideas. Nor did Coase just rely on the market for ideas to sort things out; he encouraged empirical work directly as editor of the Journal of Law and Economics and through his support to ISNIE, the Ronald Coase Institute, and other organizations. The lesson for economists from Coase's advice and his life is to do research that is useful and transformative, encourage and support other economists to do the same, and work to assure that the market for ideas in economics is, indeed, free. This is a tall order. A modest first step would be to study the ways in which economics research is selected, financed, disseminated, and rewarded to understand better the forces working for and against empirical work on real world institutions, so that barriers can be identified and overcome.

By example, Coase showed the importance of other traits as well: generosity and tolerance towards other scholars, bravery before orthodoxy, and unflinching defense of your argument. The FCC paper would never have led to "The Problem of Social Cost" had Coase wavered before the onslaught of criticism. Stubborn defense of a bad idea is not a desirable trait, however; it helped that Coase was usually right. Although Coase was always firm when defending his views, he was never strident; he did not need to be. His famous response to Posner ("Coase on Posner on Coase" 1993) combined humor, elegance, and breathtakingly incisive prose, the tools of a devastatingly effective opponent. ${ }^{10}$

Coase concluded his Nobel acceptance speech with these words: “. . a scholar must be content with the knowledge that what is false in what he says will soon be exposed and, as for what is true, he can count on ultimately seeing it accepted, if only he lives long enough" (1992: 719). Coase lived long enough to see some of his most iconoclastic ideas triumph, and to see an army of younger scholars, nurtured by his writings, his example, and his support, ready to fight the battles he had not yet won. 


\section{NOTES}

1. Afterwards the University of Virginia produced a secret "self-study" report that also argued that the TJC economists held a "particular" viewpoint (Breit 1986, p. 9), and the TJC's relations with the University soured.

2. It took another 35 years before the FCC finally introduced spectrum auctions. Hazlett et al. (2011, p. S125) estimated that spectrum auctions from 1994-2009 earned the US government about $\$ 53$ billion and avoided welfare loses of $\$ 17$ billion.

3. "The Problem of Social Cost" is one of the most cited articles in social science; cited more than 20,500 times according to Shirley (2013).

4. According to Shirley $(2013$, p. 4) a 2003 survey of economics textbooks and a 2010 survey of the most cited and most recent articles on the Coase Theorem concluded that 75 to 80 percent of them misrepresented Coase's argument.

5. As Medema (1995) pointed out, Coase recognized the need for some departures from reality, but objected to the treatment of factors in ways that "bear little correspondence to their existence and operation in reality" such as rational utility maximizing consumers, and the exclusion of factors "necessary for understanding the workings of the economic system (e.g., institutions and transaction costs) and for evaluating economic policy (e.g., the costs of government)" (pp. 9-10).

6. Allen (2015) argues that Coase's most famous papers, albeit not mathematical, are theoretical.

7. Besides the Ronald Coase Institute (2001), Coase supported the Contracting and Organizations Research Institute at the University of Missouri at Columbia (2000), the Ronald Coase Center for the Study of the Economy at Zhejiang University (2012), and the Ronald Coase Center for the Study of Property Rights at the University of Hong Kong (2013).

8. Preparing an article for a special issue on the "Problem of Social Cost", I did an unscientific search for analyses that compared total costs and benefits of alternative approaches to pollution and found shockingly few (Shirley, 2013).

9. Private conversations with the author.

10. Just to give a small flavor, consider this: "At the conference I expressed my astonishment that Posner, writing about my views, had not bothered to ask me what they were and I quoted the saying from the Wallet of Kai Lung: 'it is a mark of insincerity of purpose to spend one's time looking for the Sacred Emperor in the low-class tea-shops.' I have since concluded that this does Posner as an injustice. The trouble with Posner, to use a phrase of Frank Knight's, is not with what he doesn't know but with what he knows that 'ain't so"' (Coase, 1993, p. 98).

\section{BIBLIOGRAPHY}

Allen, D. (2015), 'Coasean Method: Lessons From the Farm', Journal of Institutional Economics, 11 (1), 93-110.

Breit, W. (1986), "Creating the "Virginia School": Charlottesville as an Academic Environment in the 1960s', Fairfax: Center for Study of Public Choice Working Paper.

Coase, R.H. (1937), 'The Nature of the Firm', Economica, 4 (16), 386-405.

Coase R.H. (1946), 'The Marginal Cost Controversy', Economica, 13 (51), 169-82.

Coase, R.H. (1959), 'The Federal Communications Commission', Journal of Law and Economics, 2 (October), 1-40.

Coase, R.H. (1960), 'The Problem of Social Cost', Journal of Law and Economics, 3 (October), 1-44.

Coase, R.H. (1974), 'The Lighthouse in Economics', Journal of Law and Economics, 17 (2), $357-76$. 
Coase, R.H. ([1981] 1994b), 'How Should Economists Choose?', in R.H. Coase, Essays on Economics and Economists, Chicago: University of Chicago Press, pp. 15-33.

Coase, R.H. (1990), The Firm, the Market, and the Law, Chicago: University of Chicago Press (paperback edition).

Coase, R.H. (1992), 'The Institutional Structure of Production', The American Economic Review, 82 (4), 713-19. Lecture delivered in Stockholm, Sweden accepting the Alfred Nobel Memorial Prize in Economic Sciences, December 9, 1991.

Coase, R.H. (1993), 'Coase on Posner on Coase', Journal of Institutional and Theoretical Economics, 149 (1), 96-8.

Coase, R.H. (1994a), 'Adam Smith's View of Man', in R.H. Coase, Essays on Economics and Economists, Chicago: University of Chicago Press, pp. 95-129.

Coase, R.H. (1994c), 'The Wealth of Nations', in R.H. Coase, Essays on Economics and Economists, Chicago: University of Chicago Press, pp. 75-94.

Coase, R.H. (1995), 'My Evolution as an Economist', in W. Brent and R.W. Spenser (eds.), Lives of the Laureates: Thirteen Nobel Economists, 3rd edn, Cambridge, MA: The MIT Press, pp. 227-50.

Coase, R.H. (1996), 'Law and Economics and A.W. Brian Simpson', The Journal of Legal Studies, 25 (1), 103-19.

Coase, R.H. (1998), 'Comment on Thomas W. Hazlett: Assigning Property Rights to Radio Spectrum Users: Why Did FCC License Auctions Take 67 Years?', Journal of Law and Economics, 41 (2), 577-80.

Coase, R.H. (1999), 'The Task of the Society', Opening address of the annual conference of ISNIE, Washington, DC, September 17, 1999. ISNIE Newsletter, 2 (2), 1-6.

Coase, R.H. (2000), 'The Acquisition of Fisher Body by General Motors', Journal of Law and Economics, 43 (1), 15-31.

Coase, R.H. (2006), 'The Conduct of Economics: The Example of Fisher Body and General Motors', Journal of Economics \& Management Strategy, 15 (2), 255-78.

Coase, R.H. (2010), 'Interview with Professor Ronald Coase on his 100th Birthday', available at: http://www.coase.org/coaseonline.htm (accessed on 10 January 2015).

Coase, R.H. and N. Wang (2012), How China Became Capitalist, Basingstoke and New York: Palgrave Macmillan.

Friedman, M. ([1952] 1966), 'The Methodology of Positive Economics', in M. Friedman, Essays in Positive Economics, Chicago: University of Chicago Press, pp. 3-16, 30-43.

Hayek, F. (1984), 'Letter of November 29, 1984 Nominating Ronald Coase for the Sveriges Riksbank Prize in Economic Sciences in Memory of Alfred Nobel', Hayek Files, Hoover Institution, Stanford University.

Hazlett, T.W., D. Porter, and V. Smith (2011), 'Radio Spectrum and the Disruptive Clarity of Ronald Coase', Journal of Law and Economics, 54 (4), S125-S165.

Klein, B., R.G. Crawford, and A.A. Alchian (1978), 'Vertical Integration, Appropriable Rents and the Competitive Contracting Process', Journal of Law and Economics, 21 (2), 297-326.

Landes, W., D. Carlton, and F. Esterbrook (1983), 'On the Resignation of Ronald H. Coase', Journal of Law and Economics, 26 (1), iii-iv.

Levy, David M. and Sandra J. Peart (2014), “"Almost Wholly Negative": The Ford Foundation's Appraisal of the Virginia School' (August 22, 2014). Available at: http://ssrn.com/ abstract $=2485695$ or http://dx.doi.org/10.2139/ssrn.2485695 (accessed 15 January 2015).

Medema, Steven G. (1995), 'Ronald Coase on Economics and Economic Method', History of Economics Review, 24, 1-22.

Peltzman, S. (2011), 'Ronald Coase and the Methodology of Economics', Journal of Law and Economics, 54 (4), S15-S29.

Pigou, A.C. (1932), The Economics of Welfare, London: Macmillan.

Shirley, M.M. (2013), 'Battles Lost and Wars Won: Reflections on the Problem of Social Cost', Journal of Natural Resources Policy Research, 5 (4), 243-7.

Stigler, G.J. (1966) The Theory of Price, 3rd edn, New York: Macmillan.

Stigler, G.J. (1988), Memoirs of an Unregulated Economist, New York: Basic Books Inc.

Wang, N. (2014), 'Ronald H. Coase', Man and the Economy, 1 (1), 125-40. 